Provided by the author(s) and University of Galway in accordance with publisher policies. Please cite the published version when available.

\begin{tabular}{|c|c|}
\hline Title & $\begin{array}{l}\text { Bodipy-ruthenium(II) tris-bipyridyl dyads for homogeneous } \\
\text { photochemical oxidations }\end{array}$ \\
\hline Author(s) & Farràs, Pau; Benniston, Andrew C. \\
\hline $\begin{array}{c}\text { Publication } \\
\text { Date }\end{array}$ & 2014-10-28 \\
\hline $\begin{array}{l}\text { Publication } \\
\text { Information }\end{array}$ & $\begin{array}{l}\text { Farràs, Pau, \& Benniston, Andrew C. (2014). Bodipy- } \\
\text { ruthenium(II) tris-bipyridyl dyads for homogeneous } \\
\text { photochemical oxidations. Tetrahedron Letters, 55(51), 7011- } \\
\text { 7014. doi: http://dx.doi.org/10.1016/j.tetlet.2014.10.119 }\end{array}$ \\
\hline Publisher & Elsevier \\
\hline $\begin{array}{l}\text { Link to } \\
\text { publisher's } \\
\text { version }\end{array}$ & http:/dx.doi.org/10.1016/j.tetlet.2014.10.119 \\
\hline Item record & http://hdl.handle.net/10379/5971 \\
\hline DOI & http://dx.doi.org/10.1016/j.tetlet.2014.10.119 \\
\hline
\end{tabular}

Downloaded 2023-04-26T10:48:20Z

Some rights reserved. For more information, please see the item record link above. 


\section{Graphical Abstract}

Bodipy-ruthenium(II) tris-bipyridyl dyads

Leave this area blank for abstract info.

for homogeneous photochemical oxidations

Pau Farràs, Andrew C. Benniston

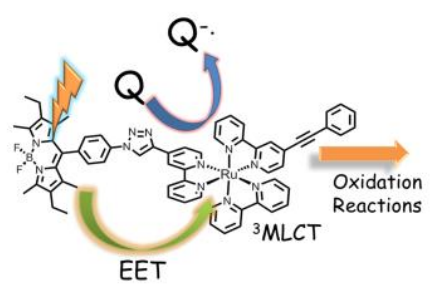




\title{
Bodipy-ruthenium(II) tris-bipyridyl dyads for homogeneous photochemical oxidations
}

\author{
Pau Farràs, * Andrew C. Benniston* \\ Molecular Photonics Laboratory, School of Chemistry, Newcastle University, Newcastle upon Tyne, NE1 7RU, UK.
}

\begin{abstract}
Two Bodipy-ruthenium(II) tris-bipyridyl dyads were synthesized for use as sensitizers in photochemical oxidation reactions of organic substrates. The synthetic strategy involved the use of a simple "click" CuAAC reaction to link a Bodipy subunit with an organometallic ruthenium(II) tris-bipyridyl complex. The linking triazole bridge was used to minimize electronic coupling between the two subunits. The dyads showed improved performance on organic substrate photo-oxidation reactions compared to the control compound without the Bodipy moiety.
\end{abstract}

The production of fuels from sunlight remains as one of the main challenges for the scientific community. ${ }^{1}$ In recent years, various steps towards efficient systems have been taken, although no example having the desired properties of stability and economic viability has been discovered. ${ }^{2}$ The main components of a full device for light-driven water splitting can be divided as catalysts for oxidation and reduction reactions, light-harvesting compounds, semiconducting electrodes for electron and hole transport and a membrane which both conducts protons and separates the generated gases. Many examples of molecular catalysts have appeared in the literature for water oxidation and proton reduction, some of them exhibiting incredible performances. ${ }^{3}$ However, there are not many examples of sensitizers for water oxidation, limited mainly by the high oxidation potential needed to drive the reaction and their stability in aqueous media. Common molecular sensitizers for water splitting found in the literature are ruthenium(II) tris(bipyridine) and porphyrin derivatives. ${ }^{4}$ In both cases, the molecules are directly attached to a semiconductor and fast recombination reactions from the injected electrons are observed. ${ }^{5}$

On the other hand, the use of 4,4-difluoro-4-bora-3a,4a-diazas-indacene (Bodipy) as a chromophore has become very popular owing to its exceptional optical properties, photostability, and ease of preparation and purification. Very complicated structures have been prepared based on dendritic scaffolds, ${ }^{6}$ cassette lightharvesters ${ }^{7}$ or multi-dyads showing the versatility of such dyes. ${ }^{8}$ They can be easily functionalised to tune redox and optical properties to meet the demands for the water oxidation reaction. Recently, Bodipy dyes have been published as sensitizers for light-driven hydrogen production although no examples in photochemical oxidation reactions have appeared so far. ${ }^{9}$

In view of such considerations, we envisioned the possibility of designing Bodipy-ruthenium dyads with directional control of electron and hole transport within the sensitizer to minimise recombination reactions and improve the performance of the system. Both subunits are bridged by a triazole linker to avoid coupling between the Bodipy and the ruthenium complex. Moreover, dyad BDR2 has an ethylene-bipyridyl ligand that is easier to reduce than bipyridine and should direct the electron towards this end of the molecule. The two targeted molecules are shown in Scheme 1 along with the synthetic procedure.

The preparation of dyads BDR1 and BDR2 required the synthesis of the new bipyridyl ligand BDB (Scheme 1). The starting material azidophenyl-Bodipy (1) represents a good candidate to introduce Bodipy fluorophores in organometallic complexes given the reactivity of the azido group. ${ }^{10}$ The key step for the preparation of the ligand relies on the flexibility and selectivity of the "click" CuAAC coupling reaction. This synthetic modular approach opens up the preparation of a large variety of dyads with different types of organic chromophores. Coupling of $\mathbf{1}$ with $\mathbf{2}$ under "click" conditions afforded BDB in good yield $(63 \%)$ after careful chromatography $\left(\mathrm{Al}_{2} \mathrm{O}_{3}\right.$, eluent: $\mathrm{CH}_{2} \mathrm{Cl}_{2}$ /petroleum ether, $1: 1$ then 1:0) as a red crystalline material. The ${ }^{1} \mathrm{H}$ NMR spectrum for BDB displayed, along with signals for the Bodipy and bpy groups, a typical singlet at $\delta 8.63$ corresponding to the triazole group.

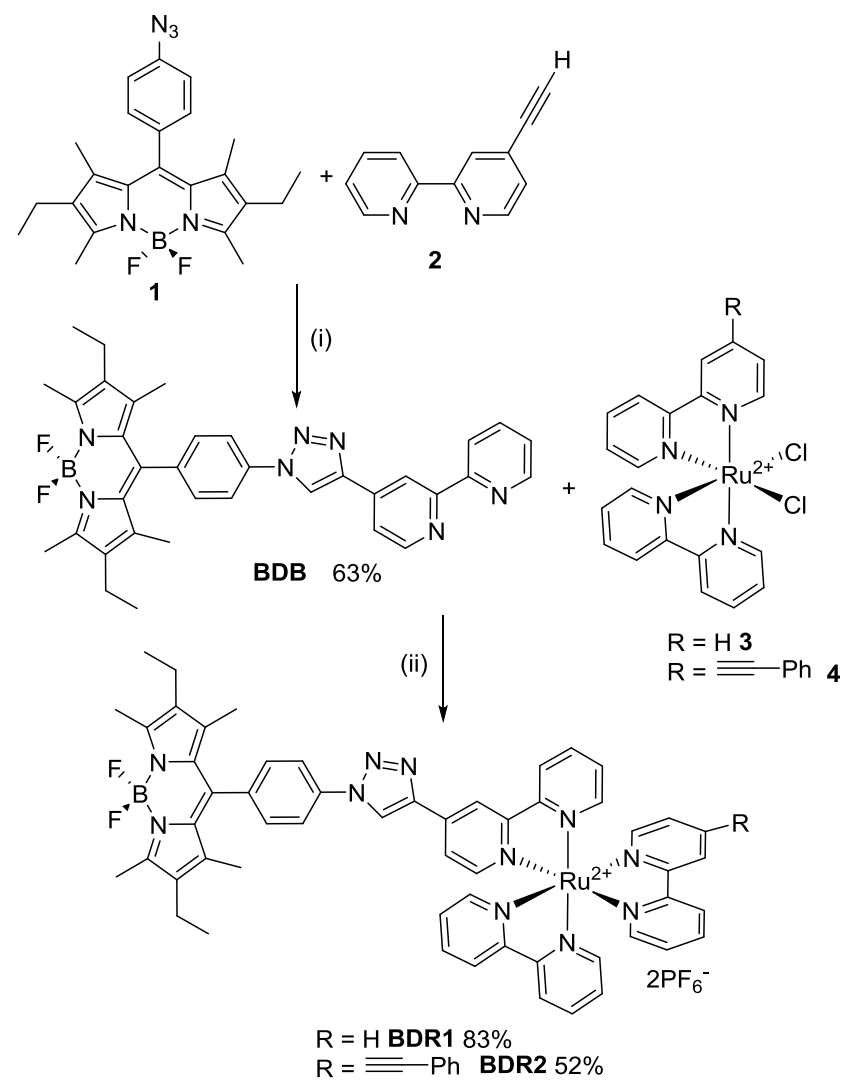

Scheme 1. Reagents and conditions: i) $\mathrm{CuSO}_{4}$, sodium ascorbate, $\mathrm{CH}_{3} \mathrm{CN} / \mathrm{H}_{2} \mathrm{O}, 40{ }^{\circ} \mathrm{C}, 18 \mathrm{~h}$; ii) $\mathrm{EtOH} / \mathrm{H}_{2} \mathrm{O}$, reflux, $18 \mathrm{~h}$, $\mathrm{KPF}_{6}(\mathrm{aq})$. Note: for simplicity the R group for $\mathbf{B D R 2}$ is placed in an arbitrary position.

The ligand BDB was complexed using the classical procedure of reacting it with stoichiometric amounts of a metal precursor. 
The synthetic route used either $\left[\mathrm{Ru}^{\mathrm{II}} \mathrm{Cl}_{2}\left(2,2^{\prime} \text {-bipyridine }\right)_{2}\right] \mathbf{3}$ or the phenylacetylene derivative $\mathbf{4}$ as metal salts under ethanolic aqueous solution reflux conditions. The purple precursor 4 was prepared by the reaction of $\left[\mathrm{Ru}^{\mathrm{II}} \mathrm{Cl}_{2}(\mathrm{DMSO})_{2}(2,2\right.$-bipyridine $\left.)\right]$

with 2 in hot DMF. It should be noted that the complex is a mixture of diastereoisomers arising because of the relative positioning of the phenylacetylene group with respect to the chloride ligands and the possibility of $\Delta$ and $\Lambda$ isomers. No attempt was made to separate the diastereoisomers, and so the final dyad BDR2 is also a mixture of stereoisomers.

All complexes were isolated as the hexafluorophosphate salts by column chromatography and recrystallization from adequate solvents. Their molecular structures were unambiguously assigned by using ${ }^{1} \mathrm{H},{ }^{13} \mathrm{C},{ }^{19} \mathrm{~F}$ and ${ }^{11} \mathrm{~B}$ NMR spectroscopy, electrospray mass spectrometry and elemental analysis. Both dyads analysed by ESI-MS gave an intense molecular peak with the expected isotopic profile corresponding to the loss of two $\mathrm{PF}_{6}{ }^{-}$counter anions assigned to a doubly charged species.

The UV/visible absorption bands of the free ligand and dyad complexes were collected in $\mathrm{CH}_{3} \mathrm{CN}$ (Table 1, Figure 1). The absorption and fluorescence profile for the free ligand is typical for a Bodipy derivative. ${ }^{11}$ The electronic absorption spectrum for BDB is dominated by a sharp band centred at $523 \mathrm{~nm}\left(\varepsilon_{\mathrm{MAX}}=\right.$ $75000 \mathrm{M}^{-1} \mathrm{~cm}^{-1}$ ) which is assigned to the lowest-energy spinallowed $\pi-\pi^{*}$ transitions involving the Bodipy moiety. The shoulder at the higher energy side of this intense absorption is typical of the vibronic sequence for a dipyrromethene framework. The other weaker transition at $c a .380-400 \mathrm{~nm}$ is due to the $\mathrm{S}_{0} \rightarrow \mathrm{S}_{2}$ transition. The basic fluorescence spectrum $\left(\lambda_{\mathrm{FLU}}=541\right.$ $\mathrm{nm})$ at room temperature is on a par with a simple Bodipy derivative, along with the luminescence quantum yield $\Phi_{\mathrm{LuM}}=$ 0.66. There is no evidence to suggest that the appended bpy ligand affects the Bodipy group.

In the case for dyads BDR1 and BDR2, the presence of the metal centre is seen by the appearance of bands between 400 and $450 \mathrm{~nm}$. These new bands correspond to the metal-to-ligand charge-transfer (MLCT) transitions between the ruthenium(II) centre and the bpy ligands. For BDR2, where the metal centre is surrounded by three different bpy ligands, more electronic transitions arise as evidenced by the presence of a broader band in the region. For both BDR1 and BDR2 there is a good match between the observed absorption spectrum and a summation of the individual components (see Supporting Information). Any interaction between the Bodipy and ruthenium complex in the ground state is weak. In comparison to the free ligand, the complexes BDR1 and BDR2 give much weaker fluorescence associated with the Bodipy moiety (Figure 1a). The additional band observed at $630 \mathrm{~nm}$ (Figure 1b) is typical for $\mathrm{Ru}(\mathrm{bpy})$-type complexes. The total luminescence quantum yield $\left(\Phi_{\text {LUM }}\right)(a+b)$ for both complexes is around 0.03 . Preliminary femtosecond pump-probe experiments indicate that singlet-to-triplet energy transfer in DMF from the excited Bodipy to the $\mathrm{Ru}(\mathrm{II})$ component is fast $(\sim 160 \mathrm{ps})$. Nanosecond flash photolysis results support population of the Bodipy triplet state because of slow reverse energy transfer from the metal-centred ${ }^{3}$ MLCT state. A more detailed description of the excited state behaviour will be reported in a full paper.

Figure 1. Absorption (black) and emission (red) spectra for BDB (solid), BDR1 (dash) and BDR2 (dot) in acetonitrile. Note: a represents emission from the Bodipy moiety and $b$ represents emission from the ruthenium complex.

Electrochemical experiments were carried out by means of cyclic voltammetry in dry acetonitrile containing $0.1 \mathrm{M}$ tetrabutylammonium hexafluorophosphate as a supporting electrolyte. The recorded redox potentials versus SSCE are presented in Table 1. The electrochemical behaviour for the free ligand BDB is dominated by an irreversible wave in the oxidative scan, and a quasi-reversible wave upon reductive scanning. The oxidation peak at $+1.09 \mathrm{~V}$ is assigned to the formation of a Bodipy $^{+}\left(\mathrm{BD}^{+}\right)$unit; the irreversibility is also known for other polypyridyl-containing Bodipy molecules. ${ }^{12,13}$ The quasireversible wave seen at $-1.15 \mathrm{~V}$ is associated with the addition of one electron to the Bodipy site.

The dyads BDR1 and BDR2 display an irreversible wave and a quasi-reversible wave upon oxidative scanning. In the reduction scan two well-defined quasi-reversible waves are seen; an extra wave at more negative values is seen as a shoulder, and also observed in similar Ru-BD dyads reported in the literature. ${ }^{13}$

Table 1. Spectroscopic and photophysical data recorded in $\mathrm{CH}_{3} \mathrm{CN}$ at $298 \mathrm{~K}$. Oxidation and reduction potentials of the free ligands and dyad molecules $v s$. sodium saturated calomel electrode (SSCE) in acetonitrile with $0.1 \mathrm{M}$ tetrabutylammonium hexafluorophosphate as a supporting electrolyte at a scan rate of $0.1 \mathrm{~V} \mathrm{~s}^{-1}$.

Fluorescence

\begin{tabular}{lccccc}
\hline Compound & Absorption $\lambda_{\max }, \mathrm{nm}\left(\varepsilon, \mathrm{M}^{-1} \mathrm{~cm}^{-1}\right)$ & $\lambda_{\text {FLU }}, \mathrm{nm}$ & $\Phi_{\text {LUM }}$ & $\mathrm{E}_{1 / 2 \mathrm{ox}}$ & $\mathrm{E}_{1 / 2 \mathrm{red}}$ \\
\hline BDB & $377(10800), 402(8400), 493(27200), 523(75000)$ & 541 & 0.66 & 1.09 (irrev) & -1.15
\end{tabular}

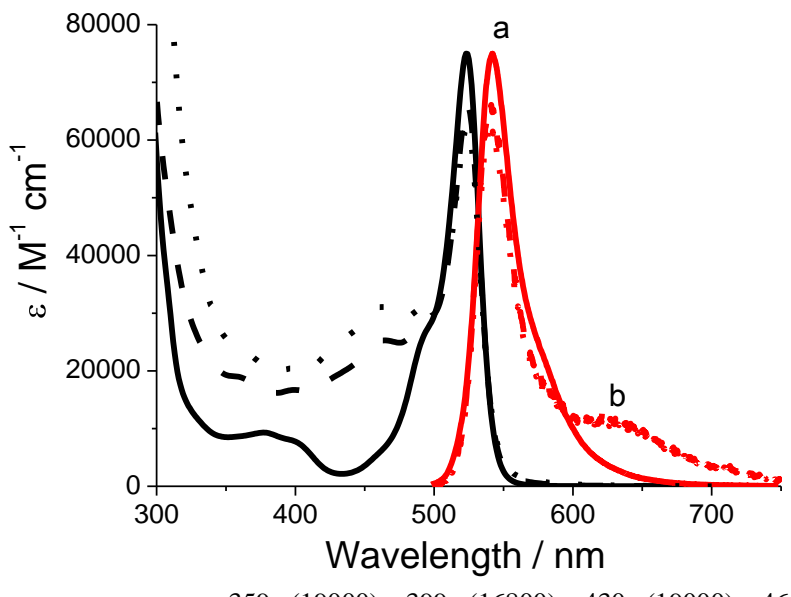


Notwithstanding, the electrochemical behaviour for BDR1 is readily understood as a near perfect overlap of the cyclic voltammograms observed for the two halves of the molecule; namely, ligand $\mathbf{B D B}$ and $\left[\mathrm{Ru}(\mathrm{bpy})_{3}\right]^{2+}$. This behaviour is observed for both dyad molecules. As an example, the BDR1 oxidative segment is dominated by an irreversible wave at +1.05 $\mathrm{V}$ (Bodipy-based) followed by a reversible one-electron wave at $+1.28 \mathrm{~V}$ (Ru-based). In the reduction side, once again is seen a wave at $-1.16 \mathrm{~V}$ (reduction of Bodipy), and three quasi-reversible waves at $-1.31,-1.54$ and $-1.76 \mathrm{~V}\left(\Delta \mathrm{E}_{\mathrm{p}}=80 \mathrm{mV}\right)$ which are typical for $\mathrm{Ru}(\mathrm{bpy})$-type complexes. ${ }^{14}$ From these results it is inferred that the $\mathrm{Ru}$ and Bodipy subunits are isolated and only minor, if any, electronic communication takes place through the bridge in the ground state.

The ability of dyads BDR1 and BDR2 to act as sensitizers in the photochemical oxidation of water and organic substrates was tested with two molecular ruthenium oxidation catalysts reported in the literature. Catalyst $\left[\mathrm{Ru}^{\mathrm{II}}(\mathrm{bda})(4 \text {-bromopyridine })_{2}\right]$ where $\left(\mathrm{H}_{2}\right.$ bda $=2,2$-bipyridine-6,6-dicarboxylic acid), RuCAT, is known to be a good water oxidation catalyst under visible light illumination using $\left[\mathrm{Ru}\left(4^{\prime}, 4-\left(\mathrm{PO}_{3} \mathrm{H}_{2}\right)_{2} \text {-bpy }\right)(\mathrm{bpy})_{2}\right]^{2+}$ as the sensitizer. ${ }^{15}$ However, the latter complex has an oxidation potential of $+1.20 \mathrm{~V} v s$. SSCE, which is higher than the oxidation potential of the $\mathrm{BD}^{\mathrm{I} / 0}$ couple in the dyads $(+1.05 \mathrm{~V})$. Electrochemical analysis by CV of a mixture of BDR1 and RuCAT is shown in Figure 2. The black trace shows the redox couples corresponding to dyad BDR1 $\left(\mathrm{BD}^{\mathrm{I} / 0}\right.$ and $\mathrm{Ru}_{\mathrm{P}}{ }^{\mathrm{IIIIII}}$ ) in a water:acetonitrile mixture.

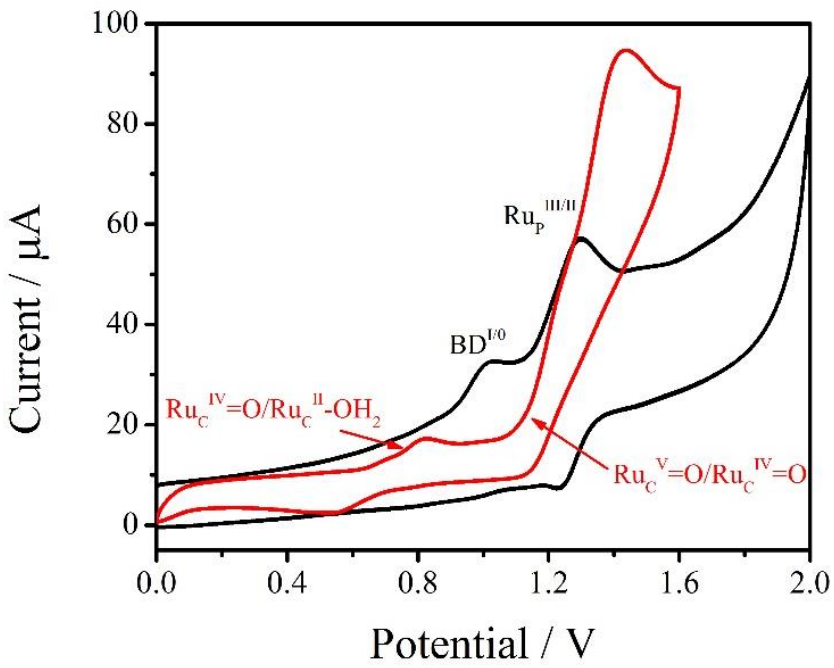

Figure 2. Redox properties of dyad BDR1 (black) and RuCAT (red) in a water:acetonitrile mixture using a glassy carbon disk electrode, a Pt wire as the auxiliary, and a SSCE as the reference electrode, at a scan rate of $100 \mathrm{mV} \mathrm{s}^{-1}$.
V). Such a species is not achievable for BDR1 because of its lower oxidation potential. However, the $\mathrm{Ru}_{\mathrm{C}}{ }^{\mathrm{IV}}=\mathrm{O}$ oxidation state can be obtained and, therefore, oxidation of organic substrates should be achieved with RuCAT and the Bodipy-Ru dyads. A second catalyst $\left\{\left[\mathrm{Ru}^{\mathrm{II}}(\mathrm{tpy})\right]_{2}(\mu-\mathrm{pyr}-\mathrm{dc})(\mu-\mathrm{OOCMe})\right\}$ [RuCAT2] was also used which is known to be a very good oxidation catalyst for organic substrates. ${ }^{16}$

The ability of dyads BDR1 and BDR2 and control compound $\left[\mathrm{Ru}(\mathrm{bpy})_{3}\right]^{2+}$ to act as sensitizers in photochemical oxidation reactions were examined for the oxidation of a variety of organic substrates and the results obtained are presented in Table 2. Typically, we used a ratio of 1:5:500:1000 of catalyst:sensitizer:substrate:electron acceptor and a white LED ring lamp $\left(0.05 \mathrm{~W} \mathrm{~cm}^{-2}\right)$ for 2.5 hours in a thermostated jacketed cell. As is observed in entries 1-4 of Table 2 for $4-\mathrm{OCH}_{3}$ $\mathrm{C}_{6} \mathrm{H}_{4} \mathrm{CH}_{2} \mathrm{OH}$, the reaction only proceeds when all components are present in the reaction. In general, the catalytic activity observed when the control compound is used is lower than when using the dyads under the same reaction conditions. Actually, the best performance in our case was obtained with dyad BDR1, that yields $65 \mathrm{TN}$ with a conversion of $13 \%$. This indicates that the presence of the Bodipy subunit in the sensitizer favors the photocatalytic reaction. The same trend is observed in entries 5-7 where RuCAT2 was used as the oxidation catalyst. In this case, the performance of RuCAT2 is improved compared to RuCAT, as expected for this type of ruthenium catalysts. Other alcohols tested with BDR1 and RuCAT2 show a very different reactivity, whereas 2-propanol is easily oxidized to acetone, 3- $\mathrm{NO}_{2}$ $\mathrm{C}_{6} \mathrm{H}_{4} \mathrm{CH}_{2} \mathrm{OH}$ only yields $25 \mathrm{TN}$ with a conversion of $5 \%$.

Table 2. Photocatalytic oxidation of a variety of substrates using dyads BDR1 and BDR2 and control compound $\left[\mathrm{Ru}(\mathrm{bpy})_{3}\right]^{2+}$ in aqueous solution. ${ }^{\mathrm{a}}$

\begin{tabular}{|c|c|c|c|c|}
\hline Entry & Sensitizer & Cat & Substrate & TN (Conv. \%) \\
\hline 1 & - & RuCAT & $4-\mathrm{OCH}_{3}-\mathrm{C}_{6} \mathrm{H}_{4} \mathrm{CH}_{2} \mathrm{OH}$ & - \\
\hline 2 & {$\left[\mathrm{Ru}(\mathrm{bpy})_{3}\right]^{2+}$} & & & $50(10)$ \\
\hline 3 & BDR1 & & & $65(13)$ \\
\hline 4 & BDR2 & & & $65(13)$ \\
\hline 5 & {$\left[\mathrm{Ru}(\mathrm{bpy})_{3}\right]^{2+}$} & RuCAT2 & $4-\mathrm{OCH}_{3}-\mathrm{C}_{6} \mathrm{H}_{4} \mathrm{CH}_{2} \mathrm{OH}$ & $70(14)$ \\
\hline 6 & BDR1 & & & $100(20)$ \\
\hline 7 & BDR2 & & & 95 (19) \\
\hline 8 & BDR1 & RuCAT2 & 4- $\mathrm{Br}-\mathrm{C}_{6} \mathrm{H}_{4} \mathrm{CH}_{2} \mathrm{OH}$ & $100(20)$ \\
\hline 9 & & & 2-propanol & $175(35)$ \\
\hline 10 & & & $3-\mathrm{NO}_{2}-\mathrm{C}_{6} \mathrm{H}_{4} \mathrm{CH}_{2} \mathrm{OH}$ & $25(5)$ \\
\hline
\end{tabular}

The red trace in Figure 2 shows the formation of the $\mathrm{Ru}_{\mathrm{C}}{ }^{\mathrm{II}}-\mathrm{OH}_{2}$ species from the water oxidation catalyst RuCAT and its higher oxidation states. Upon addition of water, RuCAT coordinates an aquo ligand which modulates its redox properties. It is known that for water oxidation to take place the generation of at least a $\mathrm{Ru}_{\mathrm{C}} \mathrm{v}^{\mathrm{V}}=\mathrm{O}$ species is needed (electrocatalytic wave starting at +1.20

\begin{tabular}{|c|c|c|c|c|}
\hline 11 & {$\left[\operatorname{Ru}(\mathrm{bpy})_{3}\right]^{2+}$} & RuCAT2 & 4-Br- $\mathrm{C}_{6} \mathrm{H}_{4} \mathrm{SMe}$ & $305(61)$ \\
\hline 12 & BDR1 & & & $420(84)$ \\
\hline 1 & BDR2 & & & $415(83)$ \\
\hline
\end{tabular}


Reaction conditions: photosensitizer $(0.1 \mathrm{mM}) /$ catalyst $\quad(0.02$ $\mathrm{mM}) /$ substrate $(10 \mathrm{mM}) /\left[\mathrm{Co}^{\text {III }}\left(\mathrm{NH}_{3}\right)_{5} \mathrm{Cl}\right]^{2+}(20 \mathrm{mM})$ irradiated with a white LED ring lamp $\left(0.05 \mathrm{~W} \mathrm{~cm}^{-2}\right)$ at $298 \mathrm{~K}$ in a borate buffer aqueous solution (pH 7, $20 \mathrm{mM})$.

Sulfides were also tested as substrates as indicated in entries 11-13, under the same conditions as the previous substrates, giving a good TN of 420 that represents a conversion of $84 \%$. Again, the use of the control compound gave a lower conversion yield of $61 \%$ with a $305 \mathrm{TN}$. Even though sulfides are easier to oxidize than alcohols, a general trend is observed in all cases where Bodipy-Ru dyads perform better than the control compound. However, only a minor difference is observed between both dyads, indicating that the presence of the directional ethylene-bipyridyl ligand does not affect the electron transfer processes within the sensitizer.

In conclusion, we have shown that Bodipy subunits can be readily incorporated within $\mathrm{Ru}(\mathrm{bpy})$-like sensitizers for photochemical oxidation reactions. In addition, the azidophenylBodipy proved to be a promising starting material for incorporating Bodipy subunits within donor-acceptor dyads by formation of the triazole bridge. We expect that the present systems can be modified with anchoring groups via the Bodipy or ruthenium complex site for their attachment to semiconducting metal oxides. One intention is to remove the necessity of using a sacrificial agent by coupling two half-redox reactions in a photochemical cell.

\section{Acknowledgments}

P.F. gratefully acknowledges the Royal Society for the Newton Fellowship and for the financial support. We also thank the Engineering and Physical Sciences Research Council (EPSRC) sponsored Mass Spectrometry at Swansea for the collection of mass spectra.

\section{Supplementary Material}

Supplementary data associated with this article can be found, in the online version, at http://dx.doi.org/...

\section{References}

1. (a) Directing Matter and Energy: Five Challenges for Science and the Imagination; U.S. Dept. of Energy: Washington, D. C., December, 2007; (b) Basic Research Needs: Catalysis For Energy; U.S. Dept. of Energy: Washington, D. C., August, 2007.

2. (a) Kanan, M. W.; Nocera, D. G. Science 2008, 321, 1072-1075; (b) Youngblood, W.; Lee, S.; Kobayashi, Y.; Hernandez-Pagan, E.; Hoertz, P.; Moore, T.; Moore, A.; Gust, D.; Mallouk, T. J. Am. Chem. Soc. 2009, 131, 926-927; (c) Brimblecombe, R.; Koo, A.; Dismukes, G.; Swiegers, G.; Spiccia, L. J. Am. Chem. Soc. 2010, 132, 2892-289; (d) Li, L.; Duan, L.; Xu, Y.; Gorlov, M.; Hagfeldtab, A.; Sun, L. Chem. Commun. 2010, 46, 7307-7309; (e) Gao, Y.; Ding, X.; Liu, J.; Wang, L.; Lu, Z.; Li, L.; Sun, L. J. Am. Chem. Soc. 2013, 135, 4219-4222.

3. (a) Yin, Q.; Tan, J. M.; Besson, C.; Geletii, Y. V.; Musaev, D. G.; Kuznetsov, A. E.; Luo, Z.; Hardcastle, K. I.; Hill, C. L. Science 2010, 328, 342-345; (b) Toma, F. M.; Sartorel, A.; Iurlo, M.; Carraro, M.; Parisse, P.; Maccato, C.; Rapino, S.; Gonzalez, B. R.; Amenitsch, H.; Da Ros, T., Casalis, L.; Goldoni, A.; Marcaccio, M., Scorrano, G.; Scoles, G.; Paolucci, F.; Prato, M.; Bonchio, M. Nat. Chem. 2010, 2, 826-831; (c) Fillol, J. L.; Codolà, Z.; Garcia-Bosch, I.; Gómez, L.; Pla, J. J.; Costas, M. Nat. Chem. 2011, 3, 807-813; (d) Helm, M. L.; Stewart, M. P.; Bullock, R. M.; DuBois, M. R.; DuBois, D. L. Science 2011, 333 863-866; (e) Duan, L.; Bozoglian, F.; Mandal, S.; Stewart, B.; Privalov, T.; Llobet, A.; Sun, L. Nat. Chem. 2012, 4, 418-423.
4. (a) Puntoriero, F.; La Ganga, G.; Sartorel, A.; Carraro, M.; Scorrano, G.; Bonchio, M.; Campagna, S. Chem. Commun. 2010, 46, 4725-4727; (b) Moore, G. F.; Konezny, S. J.; Song, H. E.; Milot, R. L.; Blakemore, J. D.; Lee, M. L.; Batista, V. S.; Schmuttenmaer, C. A.; Crabtree, R. H.; Brudvig, G. W. J. Phys. Chem. C 2012, 116, 4892-4902.

5. (a) Hanson, K., Torelli, D. A.; Vannucci, A. K.; Brennaman, M. K; Luo, H. L.; Alibabaei, L.; Song, W. J.; Ashford, D. L.; Norris, M. R.; Glasson, C. R. K.; Concepcion, J. J.; Meyer, T. J. Angew. Chem. Int. Ed. 2012, 51, 12782-12785; (b) Nayak, A.; Knauf, R. R.; Hanson, K.; Alibabaei, L.; Concepcion, J. J.; Ashford, D. L.; Dempsey, J. L.; Meyer, T. J. Chem. Sci. 2014, 5, 3115-3119.

6. Kostereli, Z.; Ozdemir, T.; Buyukcakir, O.; Akkaya, E. U. Org. Lett. 2012, 14, 3636-3639.

7. Ziessel, R.; Ulrich, G.; Haefele, A.; Harriman, A. J. Am. Chem. Soc. 2013, 135, 11330-11344.

8. Bandi, V.; Das, S. K.; Awuah, S. G.; You, Y.; D'Souza, F. J. Am. Chem. Soc. 2014, 136, 7571-7574.

9. (a) Sabatini, R. P.; McCormick, T. M.; Lazarides, T.; Wilson, K. C.; Eisenberg, R.; McCamant, D. W. J. Phys. Chem. Lett. 2011, 2 , 223-227; (b) Bartelmess, J.; Francis, A. J.; El Roz, K. A.; Castellano, F. N.; Weare, W. W.; Sommer, R. D. Inorg. Chem. 2014, 53, 4527-4534.

10. (a) Bai, D.; Benniston, A. C.; Hagon, J.; Lemmetyinen, H.; Tkachenko, N. V.; Clegg, W.; Harrington, R. W. Phys. Chem. Chem. Phys. 2012, 14, 4447; (b) Bai, D.; Benniston, A. C.; Hagon, J.; Lemmetyinen, H.; Tkachenko, N. V.; Harrington, R. W. Phys. Chem. Chem. Phys. 2013, 15, 9854; (c) Bai, D.; Benniston, A. C.; Whittle, V. L.; Lemmetyinen, H.; Tkachenko, N. V. ChemPhysChem 2014, 15, 3089 .

11. Benniston, A. C.; Copley, G. Phys. Chem. Chem. Phys. 2009, 11, 4124.

12. Galletta, M.; Campagna, S.; Quesada, M.; Ulrich, G.; Ziessel, R. Chem. Commun., 2005, 4222.

13. Galletta, M.; Puntoriero, F.; Campagna, S.; Chiorboli, C.; Quesada, M.; Goeb, S.; Ziessel, R. J. Phys. Chem. A 2006, 110, 4348.

14. Juris, A.; Balzani, V.; Barigelletti, F.; Campagna, S.; Belser, P., von Zelewsky, A. Coord. Chem. Rev. 1988, 84, 85-277.

15. Duan, L.; Wang, L.; Inge, A. K.; Fischer, A.; Zou, X.; Sun, L. Inorg. Chem. 2013, 52, 7844-7852.

16. Di Giovanni, C.; Poater, A.; Benet-Buchholz, J.; Cavallo, L.; Solà, M.; Llobet, A. Chem. Eur. J. 2014, 20, 3898-3902. 